Scientific Journal of October 6 University

ISSN (Print): 2314-8640

ISSN (Electronic): 2356-8119

Published by October 6 University (C) All Rights Reserved

Available online at: http:// sjou.journals.ekb.eg

Original Article
Citation: Abd El-Maksoud et al., (2014). Biochemical Alteration in Brain Natriuretic Peptide and Electrolytes in Myocardial Patients. Sci.J. of Oct. 6 Univ.2(2), 180-183.

Copyright: (C) 2014 Abd El-Maksoud et al.. This is an open-access article distributed under the terms of the Creative Commons Attribution License, which permits unrestricted use, distribution, and reproduction in any medium, provided the original author and source are credited.

\title{
Biochemical Alteration in Brain Natriuretic Peptide and Electrolytes in Myocardial Patients
}

\author{
*Abd El-Maksoud $\mathbf{H}^{1}$, Mohamed $\mathrm{K}^{2}$ and M Eman ${ }^{2}$ \\ ${ }^{1}$ Department of Biochemistry, Faculty of Verterinary Medicine, Benha University \\ ${ }^{2}$ Department of Clinical Pathology, Faculty of Verterinary Medicine, Benha University
}

\section{Received: 29-03-2014/ Revised: 20-04-2014 / Accepted: 25-04-2014}

\begin{abstract}
Brain Natriuretic Peptide (BNP) and electrolytes are important biomarker in myocardial infraction. To evaluate the relationship between Electrolyte (Sodium, Potassium, Chloride), BNP, Nitric Oxide, and Immunoglobulin in patients with myocardial infarction (MI), 25 patients with heart failure and 10 clinically healthy subjects (control), were used. The results of the present study showed the association between BNP and electrolytes, nitric oxide in addition to immunoglobulin. The results showed a decrease in sodium, potassium, chloride, and immunoglobulin except IgE and increase in BNP and NO. These parameters may be regarded as predictors or risk factors of MI.
\end{abstract}

Key Words: Myocardial infarction, Electrolyte, BNP, Nitric Oxide.

\section{Introduction}

Heart failure is a complex clinical syndrome that results from any structural or functional impairment of ventricular filling or ejection of blood. The cardinal manifestations of HF are dyspnea and fatigue, which may limit exercise tolerance, and fluid retention, which may lead to pulmonary and/or splanchnic congestion and/or peripheral edema ${ }^{(1)}$.

Clinical presentation of patients is a key component in overall evaluation of the patients with MI, in addition to electrocardiodiogram (ECG) abnormalities and the appearance of cardiac markers in the circulation. Cardiac markers help to diagnosis MI. these biomarkers of myocardial necrosis include cardiac Troponin I and $\mathrm{T}$ (cTnI and $\mathrm{cTnT}$ ), Creatine Kinase (CK), Myoglobin, Lactate Dehydrogenase, and Creatine Kinase $\mathrm{MB}(\mathrm{CK}-\mathrm{MB})^{(2)}$. NO level was correlated with endothelial dysfunction which is an important event in atherosclerosis ${ }^{(3)}$.

BNP is produced in the atrium and ventricles in different cardiac disorders, synthesis and secretion are enhanced in the ventricle of the hypertrophied heart ${ }^{(4)}$.

BNP and its esteemed role as a guide of therapy for CHF patients, the prospect of the implementation of BNP assays in routine clinical use has a lot of economic justifications. Its measurement may well provide a means to limit the number of the more specialized investigations such as echocardiography in the assessment of subjects with suspected heart failure ${ }^{(5)}$. Congestive heart failure $(\mathrm{CHF})$ is a complex clinical syndrome, characterized by multiple metabolic alterations, including those related to plasma electrolytes. Hyponatremia, hypokalemia, and hypomagnesaemia are the most common electrolyte disorders of CHF, particularly in patients in more advanced and refractory stages of the condition ${ }^{(6)}$. The present study was aimed to evaluate the biochemical alteration in brain natriuretic peptide and electrolytes in myocardial patients.

\section{Material and Methods}

Subjects and design:

This study was conducted on 25 patients admitted to Emergency Center in Damanhur hospital and other ten healthy individuals used as control. After application of the inclusion and exclusion criteria for diagnosis of AMI patients according to Alpert et al. (7). AMI was confirmed at coronary care unit (CCU) by a cardiologist guided by the world health organization (WHO) criteria

\section{Blood Sampling:}

The blood samples was poured into clean dry sterile centrifuge tube and allow coagulating at 
room temperature then centrifuged for 10 minutes at 3000 r.m.p, clear non haemolyzed sera were aspirated carefully by Pasteur pipette and transferred into dry and sterile labeled glass vials. The sera were subjected to estimation of the following parameters; Sodium $^{(8)} \operatorname{potassium}^{(9)}$ chloride ${ }^{(10)}$ nitric oxide ${ }^{(11)}, \mathrm{BNP}^{(12)}$ and immunoglobulin ${ }^{(13)}$.

\section{Statistical analysis}

Statistical analysis was done by $\operatorname{SAS}^{(14)}$

\section{Results}

The present study showed that serum sodium, potassium and chloride levels were significantly lowered in MI and significant increase in Brain Natriuretic Peptide compared to control group as in Table 1.

Serum levels of both Nitric Oxides and immunoglobulin (IgE) were significantly increased and decrease in IgG, IgM and IgA in MI patient groups compared to the control group as in Table 2. From the observed result it could be concluded that patient's with MI accompanied by low levels of serum sodium, potassium, chloride, $\operatorname{IgA}, \operatorname{IgM}$ and IgG and high levels of nitric oxide, BNP and IgE. These may be all be regarded as risk factor and could be used as diagnostic tools for MI. The present study shows the importance of BNP and nitric oxide as a predictor of MI. Also, myocardial infractions lead to increase serum $\mathrm{IgE}$.

\section{Discussion}

Millions of patients present annually with chest pain, but only $10-15 \%$ has myocardial infarction. When a patient presented with chest and an EGG recording typical of acute myocardial infarction (AMI), there is no need for diagnostic tests to confirm acute myocardial cell injury ${ }^{(15)}$. The present study showed that serum sodium, potassium and chloride level was significantly lowered in MI patients compared to control group. The results of this study were in agreement with Moses and $\mathrm{Kcs}^{(16)}$ and Rawal et al., ${ }^{(17)}$, they reported that, hyponatremia was the most common electrolyte abnormality is due to impairment of renal diluting ability related both to decrease in the delivery of glomerular filtrate to the distal tubule and to increased serum levels of antidiurtic hormone $(\mathrm{ADH})$ and also characterized in $\mathrm{CHF}^{(18)}$. Furthermore, Dan Rusinaru et al., ${ }^{(19)}$ proposed that low of sodium concentration in MI was due to non somatically mediated increase in arinine vasopressin (AVP) levels in response to arterial under filling.

Stimulation of via receptors of the vascular bed results in increased vascular resistance. While stimulation of $\mathrm{v} 2$ receptors in collecting ducts of the nephron lead to increase water reabsorption and dilution hypontermia. The Serum Chloride levels less than $100 \mathrm{mmol} / \mathrm{L}$ are called hypochloremia.
This may be caused by; $\mathrm{MI}^{(20)}$. BNP; was a significantly increased in BNP in MI patient compared to the control subjects. The results of this study were in agreement with Saeed $^{(21)}$ \& Carolyn and Strimike ${ }^{(22)}$ they reported that BNP levels are elevated in cardiac ischemia, arrhythmias, pulmonary disorders and indirectly chronic kidney disease; thus, patients with elevated BNP levels should be evaluated for the presence of these other conditions. BNP levels are predictive of clinical outcomes and therefore might be useful in making decisions with regard to treatment of congestive heart failure. The determination of BNP or NT-proBNP is one of the modern success stories in laboratory medicine. There is relationship between BNP and electrolytes, BNP increase excretion of sodium and water by increasing glomerular filtration and inhibiting renal sodium reapsorption. They also decrease secretion of aldosterone and rennin and cause vasodilatation reducing blood pressure and extra cellular fluid volume $^{(23)}$. But In contrary, BNP levels are significantly lower in obese patients with advanced heart failure, BNP with individual lipid fractions in desirable and undesirable state a positive relation with triglycerides and HDL-cholesterol and a negative relation with total and LDL- cholesterol was disclosed ${ }^{(24)}$. Nitric Oxide: Serum levels of both Nitric Oxides were significantly increased in MI patient groups compared to the control group.

The result of the present study was in agreement with Higashino et al., ${ }^{(25)}$, they reported that increased NO levels in patients with coronary artery disease and much higher in patients with multiple underlying conditions such as hyper lipidemia and hyperglycemia. The degree of decrease in nitric oxide level was correlated with the increasing number of cardiovascular risk factors. On the other hand, there was high level of NO in both acute and chronic inflammatory conditions including atherosclerosis ${ }^{(26)}$.

The role of nitric oxide in mediating many of the regulatory properties of the endothelium is now recognized, as is a growing understanding of how conditions and diseases considered to be "risk factors" for atherosclerosis cause endothelial dysfunction with loss of nitric oxide bioactivity.

This result is in contrary to Władysław et al., ${ }^{(27)}$, who reported that, reduced NO bioavailability is the hallmark of endothelial; dysfunction occurring early in cardiac diseases. The concentration of NO produced by eNOS is non toxic and is sufficient for intracellular signaling. Moreover, NO has many physiological actions that are potentially antiatherosclerotic as it inhibits a variety of actions e.g. platelet aggregation and adherence to endothelial cells. Immunoglobulin's are protein molecules. They contain antibody activity and are produced by the terminal cells of B-cell differentiation known as 'plasma cells'. There are five classes of immunoglobulin (Ig): $\operatorname{IgG}, \operatorname{IgM}, \operatorname{Ig} \mathrm{A}, \operatorname{IgD}$ and $\operatorname{IgE}$. 
The present study showed a significant increase in igE, and decrease in $\operatorname{IgG}, \operatorname{IgM}$, and $\operatorname{IgA}$ in $\mathrm{MI}$ patient groups compared to the control group This result is agreement with Marianne et al., (28) who reported that higher levels of immunoglobulin $\mathrm{E}$ in patients with ischemic heart disease may serve as evidence that the immunoglobulin takes part in the atherogenesis and in ischemic heart disease development. Also, Kołtowski et al., (29) reported Low serum IgM titers were associated with increased age, prior MI, angina pectoris, congestive heart failure, hypertension, higher body mass index.

Patients present with an increased immune reaction in the early phase of acute myocardial ischemia. IgG and IgM appeared as the immunoglobulin (30).

Conflict of Interest statement: The author declares no conflicts of interest.

Table1: Mean ( \pm S.E) of serum Sodium, Potassium , Chloride and Brain Natriuretic Peptide in patients with myocardial infarction and control healthy subjects

\begin{tabular}{|l|l|l|l|l|}
\hline Group & Sodium & Potassium & Chloride & BNP \\
\hline Control & $147.20 \pm 2.15$ & $4.22 \pm 0.11$ & $104.00 \pm 2.98$ & $22.00 \pm 0.91$ \\
\hline MI & $112.60 \pm 1.48^{*}$ & $2.94+0.12^{* *}$ & $82.8 \pm 2.35$ & $59.13 \pm 2.26^{* *}$ \\
\hline
\end{tabular}

Table 2: Mean ( \pm S.E) of serum Nitric Oxide and Immunglubulines in patients with myocardial infraction and control healthy subjects

\begin{tabular}{|c|c|c|c|c|c|}
\hline Group & NO & IgE & IgM & $\operatorname{IgA}$ & IgG \\
\hline Control & $49.80 \pm 1.79$ & $31.00 \pm 1.75$ & $99.80 \pm 3.33$ & $93.40 \pm 2.15$ & $939.60 \pm 20.15$ \\
\hline MI & $96.13 \pm 2.98^{* *}$ & $191.33 \pm 4.58^{* * *}$ & $24.93 \pm 0.94^{* * *}$ & $19.73 \pm 1.15^{* * *}$ & $643.33 \pm 18.59^{* *}$ \\
\hline
\end{tabular}

\section{References}

1. Clyde W, Mariell J, Biykem B and Javed B. Guideline for the Management of Heart Failure. 2013, 45, 1524-4539.

2. $\mathrm{Wu}$ AH, Valdes RJ and Apple F. Cardiac troponin-T immunoassay for diagnostic of acute myocardial infarction. Clin. Chem., 2004, 40, 900-907.

3. Channon KM, Qian HS and George SE. Nitric oxide synthase in atherosclerosis and vascular injury. Arterioscl Thromb Vase Boil, 2010, 20, 1873.

4. Ala-Kopsala M, Magga J, Peuhkurinen K, Leipälä J, Ruskoaho H, Leppäluoto J and Vuolteenaho O. Molecular heterogeneity has a major impact on the measurement of circulating in terminal fragments of A- and B-type natriuretic peptides. Clin Chem, 2004, 50, 1576-88.

5. Clerico A and Emdin M. Diagnostic accuracy and prognostic relevance of the measurement of cardiac natriuretic peptides: A review. Clin. Chem., 2004, 50(1), 33-50.

6. Milionis HJ, Alexandrides GE and Liberopoulos E. Hypomagnesemiaand concurrent acid-base and electrolyte abnormalities in patients with congestive heart failure. Eur J Heart Fail. 2002, 4(2), 167-173.

7. Alpert JS, Thygesen K, Antman E and Bassand P. Myocardial information redefined-a consensus document of Cardiology/American College of Cardiology committee for the redefinition of myocardial information .J Am Coll Cardial, 2010, 36, 959-969.

8. Trinder P. "Colorimetric determination of sodium in serum and plasma." Analyst. 1951, (7), 596

9. Berry MN, Mazzachi RD and Rajakovic M. Enzymatic determination of potassium in serum. Clinical Chemistry, 1989, 35, 817-20

10. Schoenfeld RG and Lewellen CJ. A colorimetric method for determination of serum chloride. Clinical Chemistry, 1962, 533-539.
11. Bories PN and Bones C. Nitrate determination in biological fluids by enzymatic one step assay with nitrate reductase. J. Clin. Chem., 1995, 41, 904-907.

12. Karl J, Borgya A, Gallusser A, Huber E, Krueger K, Rollinger W and Schenk J. Developoment of a novel, Nterminal-pro BNP(NT-pro-BNP)assay with low detection limit.Scand j. Clin.Lab-Invest, 1999, 59,177-181.

13. Johansson $\mathrm{C}$ and Johan K. Quantitative immunoglobulin determination. Acta Path. Micro. Sca. 1968, 519-530.

14. SAS. 1969. Statistical Analysis System. Users Guide Statistics. SAS Institute Gary, North Carolin.

15. Visser C, Lie K, Becker A and Durrer D. 2002. Two dimensional echocardiography. Alternative approach to quantification of acute myocardial infarction. Br Heart. pp. 512-518.

16. Moses SE and Kcs M. Acid base and electrolyte abnormalities patients with congestive heart failure. Exp Clin. Cardiol., 1997, 2(2), 140-144.

17. Rawal JR, Joshi HS, Jain SR, Roy BH, Ainchwar RV, Shah SR, Gandhi D and Chaudhri SD. Evaluation of hyponatermia in heart failure patients admitted in critical care unite: single center experience. Academic Journal, 2013, 15-22.

18. Jay N, Cohn MD, Peter R, Kowey MD, Paul K, Whelton MD, Michael L and Prisant MD. Acontemporary review by the national council on potassium in clinical practice. Arch. Intern. Med., 2000, 160, 2429-2436.

19. Dan R, Christophe T, Colin B, Mark R, Gillian A and Whalley A. Relationship of serum sodium concentration to mortality in a wide spectrum of heart failure patients with preserved and with reduced ejection fraction: an individual patient data meta-analysis; European Journal of Heart Failure, 2012, 14, 1139-1146.

20. Guevara M, Baccaro ME, Torre A, Gomez-Anson B, Rios J and Torres F. Hyponatremia is a risk factor of hepatic encephalopathy in patients with cirrhosis: a prospective 
study with time-dependent analysis. Am J Gastroenterol, 2009, 104, 1382- 1389.

21. Saeed M. Serum Electrolytes and Blood Gases, Indep Rev Jan-Mar, 2012, 14(1-3), 145-149.

22. Carolyn $L$ and Strimike R. Using $\beta$-type natriuretic peptide (bnp) in heart failure. American Journal for Nurse Practitioners, 2006, 10(3), 27-34

23. Struthers AD.1994. Ten years of natriuretic peptide research: A new dawn for their diagnostic and therapeutic use? BMJ.PP.132-129

24. Jabeen M, Furqan M, Turab M, Murad S, Zulfiqarul H and Mahmood G. Relationship of brain natriuretic peptide with serum lipids and body mass index in healthy adult males. Professional Med. J., 2010, 17(2), 274-278.

25. Higashino H, Tabuchi M, Yamagata S, Kurita T, Miya H, Mukai $\mathrm{H}$ and Miya Y. Serum nitric oxide metabolite levels in groups of patients with various diseases in comparison of healthy control subjects J. Med. Sci., 2010, 10, 1-11.

26. Whiteman $\mathrm{M}$, Rose $\mathrm{P}$ and Halliweli B. Inhibition of hypochlorous acid- induced Oxidative reactions by nitrite: is nitrite and antioxidant. Biovhvs Res Comm, 2003, 303(4), 1217-1224.

27. Władysław S, Jan B, Robert B, Jacek K and Joanna D. Immunoglobulin $\mathrm{E}$ in patients with ischemic heart disease. Cardiology Journal, 2008, 2, 122-128

28. Marianne H, Thomas K, Johan H, Knut P, Ulf de Faire and Johan F. IgM-phosphorylcholine auto antibodies and outcome in acute coronarysyndromes. Int J Cardiol., 2012,541-552.

29. Kołtowski L, Filipiak KJ, Rdzanek A, Stępień V, Tarchalska-Kryńska B, Opolski G. IgG, IgM and inflammatory markers serum concentration in patients with acute coronary syndrome: A pilot study. Kardiol Pol. 2012, 70(10), 1023-1028.

30. Kosiborod M. Serum potassium levels and mortality in acute myocardial infarction. Journal of American Medical Association, 2012, 307(2), 157-164 